Danielle Follett

Associate Professor, Université de Franche-Comté, Besançon, France

\title{
The Tension between Immanence and Dualism in Coleridge and Emerson
}

This essay focuses upon a specific philosophical tension that is found in both Coleridge and Emerson, between a Neoplatonic immanentism bordering on monism, and a subject-centered, romantic, idealist dualism. On one hand, spirit infuses nature, and humanity and nature are fundamentally akin; on the other, an essential distinction exists between humanity and nature, and spirit and nature are split. Both views inform Coleridge's and Emerson's writings to differing degrees, and their co-presence creates a certain dissonance. Although the philosophical tension is similar in each author, the ways in which each expresses and responds to it are quite different. Equally interesting is the differing degree to which each author found this tension problematic. An increasingly clear, often painful awareness of the incompatibility between quasi-monist immanence and dualist Christian idealism drove Coleridge's development as a thinker, while Emerson's syncretism allowed both views to coexist without creating overly evident or disturbing clashes. Indeed, although Emerson was a great admirer and reader of Coleridge, he did not appear to appreciate the importance of this philosophical tension for the elder poet. Emerson seemed not to realize that Coleridge's adoption of Kantian idealism and trinitarian Christianity partially constituted a flight from the moral dangers 
of monism, which he had come close to espousing in his youth.

More generally, this philosophical tension lies at the heart of romanticism, especially in the thought of post-Kantian German philosophers Schelling and Hegel, who undertook the difficult project of creating a subject-based monism. Coleridge and Emerson were thus not alone in grappling with these issues. This essay analyses these tensions, and discusses some of the ways in which Emerson, who, as it is generally agreed, was indeed a Coleridgean, was also not a Coleridgean. It would be impossible to give a full discussion of sources and influences in this article, and that is not its purpose. Many excellent and useful studies exist which detail the importance of Coleridge for Emerson's thought. ${ }^{1}$ Rather, the focus here is on the dynamic of ideas.

In order to stave off a metaphysical tangle, an initial discussion of terminology is inevitable, even if it requires an uncomfortable degree of generalization. In speaking of immanence, this article will focus mainly on the immanent presence of spirit, mind, soul or divinity within the world and nature, and less on the question of the immanence of the divine within humanity, which is much less problematic for our writers. In the West this immanentism is largely found in the Neoplatonic tradition, which espouses a dynamic emanationism positing the existence of different concentric strata of being (the One, the divine mind, the divine soul, nature), all created and infused by emanations from the One, and all linked through the circulation of the dynamic cosmic power. The divine force

\footnotetext{
${ }^{1}$ For recent extensive and detailed analyses of Coleridge's influence on Emerson, as well as complete bibliographies, see Chai, Gravil, Greenham, Harvey, Keane and Sostaric. While these studies generally demonstrate the similarities between the two authors, Sostaric's has the merit of analyzing their differences as well.
} 
being ubiquitous, Neoplatonic immanence may be said to tend toward monism. But it should not be confused with pantheism or Spinozist monism (the identity of spirit and matter). ${ }^{2}$ It remains essentially idealist, that is, spirit is superior to matter: Neoplatonism maintains a hierarchy in the strata of being, as matter is the furthest from the divine source even if it is infused with spirit. Neither dualist (i.e. vertical) nor monist (i.e. horizontal), one might say that immanence represents a varying diagonal. This ambiguous status of immanence gives rise to its dynamism: nature is neither dead/evil (dualism) nor alive/divine in its own right (hylozoism or pantheism), but animated, suffused with a divine energy. Hence the importance of the figure of the wind in romantic expressions of immanence, as a dynamic divine force that variously descends or sweeps, but always infuses.

On the other hand, the various dualist perspectives found in Plato, Descartes, Kant, and most Christian views, among others, distinguish clearly between spirit and matter: matter and the body are not only inferior to spirit but of a fundamentally different essence, and to some degree untrustworthy, evil or illusory. While the immanentist view sees nature as imbued with divine spirit in its own right, sometimes with a moral force that may redeem humanity, dualism places nature on the side of empty matter requiring spiritual redemption; without humanity, nature is barren. While the immanentist view sees humanity and nature as akin, equally suffused with divinity, transparent to the shining divine truth, in the dualist perspective humans are to some degree foreign to the world, objects are misty or just projections, and possibly the senses cannot be trusted.

\footnotetext{
${ }^{2}$ For a clear distinction between pantheism and neoplatonist immanence, see Hedley, "Pantheism...." I prefer to speak of immanence rather than "panentheism," a word whose meaning is similar but not used by our authors. On panentheism, see especially Harvey 110-116.
} 
Coleridge's early poems are informed by a religious and philosophical perspective that combines Neoplatonism, Unitarian deism, and David Hartley's associationist psychology in a somewhat unstable mix, but one which is marked by a strong immanentism. ${ }^{3}$

His poems of the 1790s contain many references to a single omnipresent God; for example in "Religious Musings" of 1794-6, he writes: "God all in all!"; "The SUPREME FAIR sole Operant..."; "There is one Mind, one omnipresent Mind, / Omnific"; "But "tis God / Diffus'd thro' all, that doth make all one whole."” The famous question of "The Eolian Harp,” expresses his early philosophy of immanence most clearly:

And what if all of animated nature Be but organic Harps diversly fram'd, That tremble into thought, as o'er them sweeps Plastic and vast, one intellectual breeze, At once the Soul of each, and God of all ?

The immanent divine force "animating" nature, the words "plastic" and "intellectual"references to the immanentism of Ralph Cudworth, the seventeenth-century Cambridge Platonist — and the figure of the wind harp itself point to the strong Neoplatonic grounding of this poem. ${ }^{6}$

However, although the omnipresent God of his Neoplatonist-Hartleyan musings was not supposed to enter into contradiction with the Christian God, Coleridge seemed to doubt

\footnotetext{
${ }^{3}$ Coleridge read the classical Neoplatonists already in high school, and Ralph Cudworth in 1995-1996. On Coleridge's early Neoplatonism, see especially Schrickx and Werkmeister. On Coleridge's relation to the Neoplatonist tradition in general, see Hedley, Coleridge, as well as his "Cudworth..." and "Philosophia...." ${ }^{4}$ Lines 43, 56, 105-106, 130-131 (CW 16:1:1:177, 179, 180).

${ }^{5}$ Lines 41-49 (CW 16:1:1:234).

${ }^{6}$ McFarland describes this passage as "an example of pure Neoplatonic Spinozism" (166); however, Spinoza was no Neoplatonist, and this description demonstrates well a fundamental, serious flaw in McFarland's book, the confusion of pantheism and Neoplatonism.
} 
this compatibility, even in "The Eolian Harp," which ends on a note expressing a certain guilty feeling for indulging in such fantasies. As Coleridge subsequently abandoned the Unitarian Church for the trinitarian Church of England and explored German idealism, his relationship with the idea of immanence evolved. His thought long retained a Neoplatonic flavor, especially regarding the idea that nature is the mirror or symbol of the divine. However, he came to doubt the presence of an active and immanent divine force within nature, progressively adopting rather the Kantian and classical Platonic view that spirit and Nature are fundamentally distinct. He wrote in 1802 , in "Dejection, an Ode":

I may not hope from outward forms to win The passion and the life, whose fountains are within. O Lady! we receive but what we give, And in our life alone does Nature live... ${ }^{7}$

"Dejection" is the anguished rejoinder of dualist idealism to quasi-monist immanence. Far from representing simply a moment when the wind is down, or inspiration momentarily absent, the poem should be understood as a sharp rejection of the philosophy elaborated in "The Eolian Harp," and not as an expansion of it. It expresses a distinct split between the human spirit and nature, here called "outward forms," a particularly dualist term. The fountains of life are located within the human subject and not in the cosmic wind, and "our life alone" is the true source of nature. The mind is not a passive, receptive instrument, as in the earlier poem, but is itself the source of life and receives only what it gives. As an expression of dualist idealism and a rejection of immanence, the poem—which deserves a much longer discussion—portrays the human subject establishing its primacy and turning upon the wind.

\footnotetext{
${ }^{7}$ Lines 45-48 (CW 16 1:2:699).
} 
In 1802, Coleridge was seeking an answer to his acute crisis of faith in Kantian and postKantian idealism. He became quite attracted to though ultimately repelled by Schelling's equally Neoplatonist attempt to reconcile nature with the spiritual subject, or immanentist monism with subject-centered idealism. In a gradual process of divesting himself of immanentism over the next twenty or so years, Coleridge maintained a more and more pronounced dualism of spirit and nature. Around 1806, he began to feel that the only way to give a full metaphysical and religious guarantee to free will was by way of the Christian mystery of the holy Trinity, that is, finding the principles of human freedom and agency in the incarnation of God in man, in the person of Jesus Christ. By at least 1825 and Aids to Reflection, immanence for him represented the presence of the divine within humanity rather than in nature, understood through the divine incarnation of the logos through the immanence of his personality within every individual. The personal God is the ground of all being; divinity is not directly present within it as an impersonal immanent force. Unity became the unity of the triune God, instead of the unity of God and world; divine truth was to be found primarily in the sacred book of the Bible rather than in the book of nature.

Coleridge's reservations about immanence are motivated by the heresy that the immanent divine force, or anima mundi of the Neoplatonists and Stoics, might usurp the place of the true Godhead, allowing for another agency besides the Absolute and the individual Will. The idea of "The SUPREME FAIR sole Operant” ("Religious Musings"), is contrary to human agency, and thus denies sin, atonement and redemption. If the same 
laws of causality govern both nature and humanity, then the human spirit is not free and man is an automaton. ${ }^{8}$ The mature Coleridge thus insisted upon the active, creative imagination and the centrality of will, grounded in trinitarian Christianity.

Although it is generally true that Coleridge's philosophical life represents a gradual replacement of immanentism by idealist and Christian dualism, it would be a mistake to see this over-simplistically as a determined or ineluctable path. Especially in his middle years, the tension between the two views was strong. ${ }^{9}$ A passage which demonstrates well Coleridge's turn toward Kantian and Platonic dualism is the following, from the discussion of method in the Friend. Poetic and convoluted, it argues unmistakably that nature cannot provide the ground of higher truth but constitutes only a "modification" of the subject's consciousness. Seeking a "ground common to the world and to man,"

man sallies forth into nature... till finding nowhere a representative of that free agency which yet is a fact of immediate consciousness... he learns at last that what he seeks he has left behind... and at once discovers and recoils from the discovery... [that nature is] a modification of his own being" $(C W 4: 1: 508-9){ }^{10}$

Dangerously close to subjectivist idealism—a view never seriously espoused by Coleridge - this passage implies a certain disappointment in being unable to find a common ground between nature and humanity. Coleridge's desire for monism is strong, yet it yields before the dualist idealism he is progressively adopting.

\footnotetext{
${ }^{8}$ In 1794, Coleridge had written: "I am a Unitarian Christian and an Advocate for the Automatism of Man." Letters 1:147.

${ }^{9}$ Modiano writes: "Coleridge held on to nature just as, like the insect struggling upstream, he prepared for yet another attempt to disengage himself from it. At no other time does nature preoccupy Coleridge as intensely or elicit reactions that swing so dramatically from amorous courtship to mistrust as in these middle years of devastating disappointments, loneliness and uncertain artistic goals." In later years "nature troubled Coleridge less because in a sense it ceased to matter as much..."(204, 205).

${ }^{10}$ On the Platonism of this passage, see Vigus 137.
} 
Coleridge also made or attempted to make revisions of his own works after publication, in order to correct what he saw as their tendency toward pantheism. Alongside this turn toward dualist idealism, the Friend includes many immanentist passages, such as when he speaks of "the light, the substance shining through [finite things....] [E]xistence is its own predicate... it is an eternal and infinite self-rejoicing.... It is absolute..." $(\mathrm{CW}$ 4:1:520, 521). Emerson, who was very fond of this essay, would not have seen the note Coleridge sent to friends in 1818, providing an addition to be inserted here, in order to preclude all suspicion of any leaning towards Pantheism, in any of its forms. I adore the living and personal God, whose Power indeed is the Ground of all Being $[\ldots]$ but who may not without fearful error be identified with the universe, or the universe to be considered as an attribute to his Deity. ${ }^{11}$

Similarly, Coleridge later distanced himself from the Neoplatonic light "shining through" nature, in the Statesman's Manual (1816). Upon looking at "the vegetable creation," he had written,

it seems as if the soul said to herself: from this state hast thou fallen! Such shouldst thou still become, thy Self all permeable to a holier power! Thy Self at once hidden and glorified by its own transparency, as the accidental and dividuous in this quiet and harmonious object is subjected to the life and light of nature which shines in it, even as the transmitted power, love and wisdom, of God over all fills, and shines through, nature! But what the plant $i s$, by an act not its own and unconsciously — that must thou make thyself to become!" (CW 6:71).

This is part of a passage that, in one of his copies and at an unknown date, Coleridge bracketed, noting: "At the time, I wrote this Work, my views of Nature were very imperfect and confused. But for this whole passage within the crotchets, una litura [an erasure] would be the best amendment. S.T.C." 12 Emerson would have been quite disappointed. Coleridge rejects his earlier idea that nature is permeated with divine light,

${ }^{11} C W 4: 1: 522$, n. 1.

${ }^{12} \mathrm{CW} 6: 71$, n. 6 . 
and especially denies that nature should be a moral model. Indeed, he wrote in 1818 that nature is "without Morality" (CW 5:2:221).

By 1825 in Aids to Reflection, divine force had drained out of nature, now demoted to the inferior status it holds in Kantian dualism: "the Power which we call Nature, may be thus defined: a Power subject to the Law of Continuity... which law the human understanding... can conceive only under the form of Cause and Effect" ( $C W$ 9:267). "Whatever is comprehended in the forms of time and space, is Nature" ( $C W$ 9:80). Nature thus became identified with the realm of cause and effect, accessed simply by the understanding. "Every appearance of origination in Nature is but a shadow of our casting. It is a reflection of our own Will or Spirit" ( $C W$ 9:268). Spirit and nature are radically separated: "and by spiritual I do not pretend to determine what the will is, but what it is not - namely, that it is not Nature" ( $C W$ 9:80). Coleridge criticizes immanence itself, alongside Wordsworth, one of its prime proponents: "Many do I know, and yearly meet with, in whom a false and sickly Taste cooperates with the prevailing fashion [and who] would fain substitute for the Jehovah of their Bible "A sense sublime / Of something far more deeply interfused...." ${ }^{\prime 13}$ Such people "reduc[e] the Creator to a mere Anima Mundi: a scheme that has no advantage over Spinosism but its inconsistency" ( $C W$ 9:402-3); they have "been educated to understand the Divine Omnipresence in any sense rather than the alone safe and legitimate one, the presence of all things to God!" (CW 9:404-5).

Coleridge became very clear at the end of his life that he found immanence to be a form of heresy. In 1827 he wrote: "Life begins in detachment from Nature, and ends in union

${ }^{13}$ CW 9:404, quoting Wordsworth's "Tintern Abbey." 
with God" (CW 12:3:417). In his posthumously published Opus Maximum, he criticizes Neoplatonism directly and at length, accusing it of "a perfect confusion of the Deity with the Universe" ( $C W$ 15:260). The Neoplatonism of "Schelling and his followers," which had once so attracted him, "attempt[s] to clothe the skeleton of the Spinozistic pantheism and breathe a new life thereunto" ( $C W$ 15:205). And in 1833, the year before his death, he wrote: "I dread even the appearance of an approximation to the Neo-platonic ProcloPlotinian Scheme \& Process" (Letters 6:961). ${ }^{14}$ The wind has fully withdrawn.

Given this evolution, it is not surprising that the very Neoplatonic Emerson would write of Coleridge: "His works are of very unequal interest; the Aids to Reflection, though a useful book I suppose, is the least valuable" (Early Lectures 1:379) Emerson allowed himself to pick and choose in Coleridge, as he did with others. The thesis that Emerson was a perfect Coleridgean is necessarily called into doubt by such eyebrow-raising statements as:

Another fault with which he is taxed in this country is his excessive bigotry to the Constitution of the Church of England. This is so apparent and so separate from the general tendency and texture of his philosophy that it will never disturb the student who is accustomed to watch his moods of thought and will skip the unnecessary pages (Early Lectures 1:380).

Emerson was thus undisturbed by Coleridge's resolute trinitarianism, in fact essential to his thought. He silently resisted the trinitarian tirade he received when visiting the elder poet in 1833, calmly appropriated Coleridge's early immanentism, inherited some of his ambiguity, and eschewed or ignored the later discourse which did not fit his own philosophy-in-progress. Many of Coleridge's strongest statements against Neoplatonism,

\footnotetext{
${ }^{14}$ According to Hedley, "it should not surprise us that Coleridge is most vehement in his critique of those to whom, intellectually, he is so close" ("Philosophia..." 230).
} 
immanence and pantheism, made in letters, marginalia or unpublished works, would not have been known to Emerson. Emerson likely recognized that Coleridge's thought was not homogeneous, and helped himself to those parts which he felt resonated most with his own.

Toward the end of Coleridge's life, the young Emerson began in his turn to plunge into Neoplatonism, and to read some of the same authors who had inspired the young Coleridge such as Cudworth and Henry More, sometimes led to them by Coleridge himself. In addition, he was quite influenced by the Neoplatonist Swedenborg, the quite Neoplatonic translations of Plato by Thomas Taylor, and a host of other authors such as the quite immanentist Wordsworth, Goethe and Boehme. Soon thereafter, around 1838, he would begin to read the classical Neoplatonists themselves, Plotinus, Iamblichus, and Proclus. Simultaneously, he received a superficial understanding of German idealist philosophy, relayed through Coleridge, Carlyle and Frederick Hedge. He was also quite struck by Bishop Berkeley's subjectivist idealism while at Harvard, and was well-read in non-Western traditions, many of them rather immanentist. Coleridge, with all his ambiguities, greatly influenced Emerson, although as Walls notes, "early in the 1840s, Emerson's active engagement with Coleridge dropped off' (124). Coleridge's ultimate rejection of immanence did not seem to register on the younger writer. It at least did not stop Emerson from developing his own strongly Neoplatonic philosophy of immanence whose tendency toward monism went well beyond that of the young Coleridge. ${ }^{15}$ His philosophy is far more homogeneous over his life than Coleridge's. One might generalize

\footnotetext{
${ }^{15}$ Harding's statement seems correct: "[The journals] show that Emerson knew what he wanted before he began reading Coleridge seriously" (235). However, one must not discount the importance of Emerson's appropriation of key Coleridgean concepts such as reason and understanding.
} 
by saying that while Coleridge gradually evolved from quasi-monist immanentism to dualist idealism, Emerson tangled these up simultaneously in single texts, creating a philosophically unstable but highly poetic tension. Essentially, Emerson makes sallies into dualist idealism, creating dissonance within his general quasi-monism, but comes back always to immanence.

Nature displays this tension remarkably. Perhaps this inconsistency is related to the "crack in it, not easy to be soldered or welded" that Emerson saw in the essay as he was finishing it. ${ }^{16}$ The main tenor of the text is one of immanence: "behind nature, throughout nature, spirit is present..." (EL 41). Its guiding idea is that humanity and nature are intimately related, not sundered: there is "an occult relation between man and the vegetable" (EL 11). The doctrine of correspondences ("The world is emblematic" [EL 24]) is central to Neoplatonic thought, and was probably inspired more directly from Swedenborg or other Neoplatonists than from Coleridge. ${ }^{17}$ The spiritual dynamism which pervades Nature from the first to the last page reveals the text's grounding in Neoplatonic immanence: "nature, whose floods of life stream around and through us..." (EL 7); "the endless circulations of the divine charity...” (EL 12); "an instantaneous in-streaming causing power" (EL 47); "nature is not fixed but fluid..." (EL 48). Emerson's emanationist view that "The moral law lies at the centre of nature and radiates to the circumference" (EL 29) contrasts strongly with Coleridge's statement that nature is

\footnotetext{
${ }^{16}$ Letters 2:32. Harvey writes that the crack is "that between nature and spirit, ontologically considered" (135), which generally converges with the tension described here.

${ }^{17}$ The lines from Coleridge much appreciated by Emerson, ("For all that meets the bodily sense I deem / Symbolical, one mighty alphabet / For infant minds") are taken from a very early, immanentist poem, "The Destiny of Nations." According to Spiller, "the doctrine of correspondence between the moral and natural laws to which they apply perhaps owes more to Swedenborg than to German idealism" ("Introduction" xxiii).
} 
“without Morality” (CW 5:2:221)

However, Emerson is influenced by dualist idealism; he is tempted by its tenets and unsure how it fits into the rest of his philosophy. The chapter devoted to "Idealism" sits uneasily with the others, as he admits: "Let [idealism] stand, then, in the present state of our knowledge, merely as a useful introductory hypothesis..." (EL 41). Emerson is responding here to Berkeley's, Coleridge's, and Kant's idealisms (Berkeley is named, $E L$ 38). ${ }^{18}$ His description of the idealist hypothesis contains a number of ideas that sharply contradict the immanentism of the rest of the text. Idealism posits a rift between humanity and nature, it considers nature as degraded and inferior to humanity, and it involves a possible skepticism as to the very existence of nature outside of the perceptions of the subject ("a noble doubt... whether nature outwardly exists" [EL 32]). Because of the subject/object dualism, idealism may lead to doubt as to the capacity of the subject to truly perceive or enter into direct relation with objects, and treats the phenomenal world as characterized by illusion, disorder, mistiness or opacity. None of these perspectives is found in neoplatonic immanentism, which sees the world as the direct, transparent emanation of the divine.

Emerson writes that "whilst the world is a spectacle, something in [man] is stable" (EL 34); this "dualism" (EL 33) means that we become aware of "the difference between the observer and the spectacle,- - between man and nature" (EL 34). Rather than receiving or witnessing the divine truth within nature, the poet "unfixes the land and the sea, and makes them revolve around the axis of his primary thought.... [He] possesses the power

${ }^{18}$ See Gravil's strong reading of the chapter on idealism as Coleridgean, 97-98. 
of subordinating nature" (34). That is, the subjective imagination, superior to nature, invests nature with meaning — rather than nature already being imbued with immanent spiritual meaning prior to the arrival of the human subject, or possibly bringing morality and meaning to humanity, as Wordsworth felt. ${ }^{19}$ Nature is here determined and perhaps even created by the human subject's activity. "We feel that the outward circumstance is a dream and a shade" (EL 37); "[we] esteem nature as an accident and an effect" (EL 33).

This “degraded" (EL 37), constructed, somewhat illusory nature is quite a different "nature" than that which infuses humanity elsewhere in the text: "the Supreme Being, does not build up nature around us, but puts it forth through us, as the life of the tree puts forth new branches and leaves through the pores of the old" (EL 41). This immanentist line would have made the trinitarian, anti-pantheist Coleridge explode in his grave. It also quite flatly contradicts Emerson's own first definition of nature, deriving from his readings in dualist idealism, as "NOT ME" $(E L 8) .{ }^{20}$ On one hand, humanity and nature are in intimate sympathy; on the other they are strictly divided. ${ }^{21}$ Emerson states elsewhere in Nature that "the problem of restoring to the world original and eternal beauty, is solved by the redemption of the soul" (EL 47). Here, he adopts the dualist idealist view that the world's unity depends on that of the subject, itself in need of redemption. Emerson does not often speak of redemption, which is not a monist concept; most often he treats both humanity and nature as inherently beautiful and divine,

\footnotetext{
${ }^{19}$ On Wordsworth's importance for Emerson, see especially Keane 125-149.

${ }^{20}$ This formulation is likely inspired from Coleridge's Biographia Literaria or Aids to Reflection, but also perhaps from Hedge and Carlyle.

${ }^{21}$ Greenham observes this tension: "in Nature Emerson is holding together two very different views.... At times he celebrates a unifying spirit, at other times he laments a falling away. [...] [In the latter sense] he is one with Coleridge, for whom God and nature are entirely separate" (93-94).
} 
corresponding with his more fundamental immanentism. "The axis of vision is not coincident with the axis of things, and so they appear not transparent but opake. The reason why the world lacks unity, and lies broken and in heaps, is, because man is disunited with himself" (EL 47). ${ }^{22}$ Here, humanity's subjective state not only engenders the opacity of the world, but also its brokenness and disjunction. Yet elsewhere in Nature, harmonious Neoplatonic light shines through transparent existence, humanity becomes selfless, and everything is interconnected: "When in fortunate hours we ponder this miracle... the universe becomes transparent, and the light of higher laws than its own, shines through it" (EL 24-25). The famous passage on the "transparent eyeball" also participates in Emerson's Neoplatonic dynamic immanence:

Standing on the bare ground, - my head bathed by the blithe air, and uplifted into infinite space, - all mean egotism vanishes. I become a transparent eye-ball; I am nothing; I see all; the currents of the Universal Being circulate through me; I am part or particle of God. (EL 10)

Even perception is inseparable from the reception of universal forces which traverse the individual who perceives. Far from the idealist model of perception as subjective creation, seeing is here understood as transparent receptivity. Emerson's use of the concept of reason is also singularly paradoxical. Although it participates in the dualist idealist tradition, famously appropriated from Coleridge's own reading of Kant, and is thus predicated upon the distinction of humanity and nature (it "shows us nature aloof, and, as it were, afloat" [LA 33]), the description of the heightened experience of the opening of the eye of reason is particularly influenced by immanentist Neoplatonism, as "spirits are seen through [objects]" (LA 33).

\footnotetext{
${ }^{22}$ Gravil makes a perceptive link between this passage and the passage from Coleridge's "Dejection: an Ode" that was cited above, and astutely notes the differential between this view and the main perspective of Nature (100).
} 
Aware that these are inconsistencies, Emerson makes various attempts to obviate if not solve the problem. He first states that whether nature actually exists or not (an idealist doubt), he still finds it worthy of veneration (EL 32). He goes on, in a somewhat Rousseauist recourse, to describe the difficulties of idealism as the "effects of culture" (EL 33). Then he seems bluntly to throw the idealist "theory" out at the end of the chapter, returning to Neoplatonic correspondences between humans and nature:

But I own there is something ungrateful in expanding too curiously the particulars of the general proposition, that all culture tends to imbue us with idealism. I have no hostility to nature, but a child's love of it. [...] I only wish to indicate the true position of nature in regard to man [...] that is, of man's connection with nature (EL 38).

Despite this apparent abandonment of the idealist theory and after complaining again that "[idealism] makes nature foreign to me, and does not account for that consanguinity which we acknowledge to it," Emerson is unable to discard it altogether: he attempts to shelve the issue by calling idealism an "introductory hypothesis, serving to apprize us of the eternal distinction between the soul and the world" (EL 41). Emerson is clearly torn, and reluctant to let go of idealist dualism, even though it enters into contradiction with his philosophy of quasi-monist interconnectivity; it coexists tensely, uncomfortably with his immanence. ${ }^{23}$ Hence the "metaphysical riot," in the words of Stanley Cavell, describing Nature (33), or the "chowder of idealisms," according to David Van Leer (x). ${ }^{24}$

\footnotetext{
${ }^{23}$ Albanese rightly emphasizes the far-reaching implications of Emerson's inconsistency, between the perspective that matter is "really real" and the idealist view that sees it as illusion. They lead to two different plans of action: harmony with nature or mastery over it (81-87). "Emerson's confusion did not cause America's confusion, but it became America's confusion..." (87).

${ }^{24}$ Harvey also relates the difficulty of "pigeonhol[ing]" Coleridge's and Emerson's metaphysics to "their conflicting views on immanence and transcendence" (110).
} 
Later works reveal similar tensions, although not always so blatantly. "The Poet" is a very Neoplatonic text, citing Jamblichus and Proclus, extolling Swedenborg, Boehme and Pythagoras, and describing the receptivity of the poet to the inspiration of the immanent divine: "suffering the ethereal tides to roll and circulate through him" (EL 459). But the next essay in the Essays: Second Series, "Experience," constitutes a powerful expression of idealism and its related skepticism about the senses. Seeing is no longer a fusion with nature and an abandonment of self to the divine forces in it, but rather "we see only what we animate" (EL 473). This statement seems to echo Coleridge's idealist affirmation in "Dejection." Emerson continues: "nature and literature are subjective phenomena" (EL 487), and "it is the eye which makes the horizon" (EL 487). Idealist terminology of "subject" and "object" informs the essay, while in "The Poet," nature is never considered an "object."

"Nature" (Second Series), several pages later, likewise demonstrates such tensions. Most of the essay is characteristically Neoplatonic, describing the interrelations between man and nature in a version of the great chain of being that is influenced by ambient theories of evolution: nature is "a system in transition [...] trees are imperfect men" (EL 547). A "guiding identity" unites all things, and the monist tendency of immanentism is heightened: "things are so strictly related.... [I]dentity makes us all one" (EL 548). And yet, shortly before the end of the essay — reproducing the structure of Nature — an idealist perspective encroaches, as Emerson argues that human aspirations are never fully realized by nature, and that we are foreign to it: "we are encamped in nature, not domesticated" (EL 552). The landscape is disappointing and deceptive: "the poet finds 
himself not near enough to his object. The pine-tree, the river, the bank of flowers before him, does not seem to be nature. Nature is still elsewhere" (EL 553). The essay here adopts the terminology of subject and object, and "nature" is made to represent an unattainable ideal rather than the present harmonious whole described earlier. However, as the essay closes, like in Nature, there is a "but" (EL 554), and unity returns: "we traverse the whole scale of being, from the centre to the poles of nature.... Here is no ruin, no discontinuity, no spent ball. The divine circulations never rest nor linger" (EL 555). Immanence has the last word. Dualist idealism makes incursions into Emerson's thought, creates tensions, but he ultimately favors Neoplatonic immanence, and remains a great lover of the wind.

It could be argued that Emerson attempted to "resolve" this tension by simply allowing the two views to coexist within an all-encompassing syncretism, as though their incompatibility were not problematic. Perhaps it is an example of his philosophy of compensation and polarity. In "Plato; or, the Philosopher," Emerson writes that Plato was "a sound, sincere, and catholic man, able to honor, at the same time, the ideal, or laws of the mind, and fate, or the order of nature" (EL 636). Willful idealism and pantheist fatalism may perhaps coexist unproblematically for a sound and "catholic" person; monism and dualism may perhaps be embraced simultaneously, for, as Emerson states, "two cardinal facts lie forever at the base; the one, and the two" (EL 637). However, it is not certain that the dissonance was unproblematic for him. Coleridge, for his part, was decidedly less catholic. Although he also believed in polarities, he would not have abided with the idea that any polarity could be legitimate; some pairs are strictly incompatible, 
like pantheism and Christianity, monism and dualism. The difference of attitudes toward this tension reveals one of the important distinctions between Coleridge and Emerson.

\section{Works Cited}

Albanese, Catherine L. Nature Religion in America: From the Algonkian Indians to the New Age. Chicago: University of Chicago Press, 1990.

Cavell, Stanley. The Senses of Walden. San Francisco: North Point Press, 1981.

Chai, Leon. The Romantic Foundations of the American Renaissance. Ithaca: Cornell University Press, 1987.

Coleridge, Samuel Taylor. Collected Works. Ed. Kathleen Coburn. 16 vols. Princeton: Princeton University Press, 1971-2002. (CW).

---. Collected Letters of Samuel Taylor Coleridge. Ed. Earl Leslie Griggs. 6 vols. Oxford: Clarendon, 1956-1971.

Emerson, Ralph Waldo. Essays and Lectures. Ed. Joel Porte. New York: Library of America, 1983. (EL). 
---. The Early Lectures of Ralph Waldo Emerson. Ed. Stephen E. Whicher and Robert E. Spiller. 3 vols. Cambridge: Harvard University Press, 1966-1972.

---. The Letters of Ralph Waldo Emerson. Ed. Ralph L. Rusk. New York: Columbia University Press, 1939.

Gravil, Richard. Romantic Dialogues: Anglo-American Continuities, 1776-1862. Basingstoke: MacMillan, 2000.

Greenham, David. Emerson's Transatlantic Romanticism. Basingstoke: MacMillan, 2012.

Harvey, Samantha. Transatlantic Transcendentalism: Coleridge, Emerson and Nature. Edinburgh: Edinburgh University Press, 2013.

Hedley, Douglas. "Pantheism, Trinitarian Theism and the Idea of Unity: Reflections on the Christian Concept of God.” Religious Studies 32.1 (Mar., 1996): 61-77.

Hedley, Douglas. Coleridge, Philosophy and Religion: Aids to Reflection and the Mirror of the Spirit. Cambridge: Cambridge University Press, 2000.

Hedley, Douglas. "Cudworth, Coleridge and Schelling." Coleridge Bulletin 16 (Winter 2000): 63-70. 
Hedley, Douglas. "Philosophia Trinitatis: Coleridge, Pantheism, and a Christian Cabbala." Coleridge's Assertion of Religion: Essays on the Opus Maximum. Ed. Jeffrey W. Barbeau. Louvain: Peeters, 2006. 213-231.

Harding, Anthony John. "Coleridge and Transcendentalism." The Coleridge Connection. Ed. Richard Gravil and Molly Lefebure. Basingstoke: Macmillan, 1990. 233-53.

Keane, Patrick J. Emerson, Romanticism and Intuitive Reason: The Transatlantic "Light of All Our Day." Columbia: University of Missouri Press, 2005.

McFarland, Thomas. Coleridge and the Pantheist Tradition. Oxford: Clarendon Press, 1969.

Modiano, Raimonda. Coleridge and the Concept of Nature. Basingstoke: Macmillan, 1985.

Schrickx, W. "Coleridge and the Cambridge Platonists." Review of English Literature 7.1 (1966): 71-91.

Sostaric, Sanja. Coleridge and Emerson: A Complex Affinity. Diss. Ruprecht, 2000.

Spiller, Robert E. "Introduction.” The Collected Works of Ralph Waldo Emerson, Volume 
1: Nature, Addresses and Lectures. Cambridge: Harvard, 1971.

Van Leer, David. Emerson's Epistemology: The Argument of the Essays. Cambridge:

Cambridge University Press, 1986.

Vigus, James. Platonic Coleridge. London: Legenda, 2009.

Walls, Laura Dassow. "Ralph Waldo Emerson and Coleridge's American Legacy."

Coleridge's Afterlives. Ed. James Vigus and Jane Wright. Basingstoke: Macmillan, 2008.

$112-127$. 